\title{
New Journals
}

This year, Nature's annual new journals review supplement will appear in the 7 November issue. Publishers and learned societies are invited to submit journals for review, as well as details of any eligible electronic journals, taking note of the following criteria:

- Journals must have first appeared during or after June 2000 and published at least four separate issues by the end of June 2002.

- Journals covering any aspect of science are eligible, although those dealing with clinical medicine and pure mathematics are excluded, as are newsletters and publications of abstracts.

-Frequency of publication must be at least three times a year.

- The main language must be English.

-Deadline for submissions is 15 July 2002.

For each eligible title, please send at least four different issues (the first, the most recent and any two others), together with full details of subscription rates, to Mary Purton, Nature, The Macrnillan Building, 4 Crinan Street, London N1 9XW, UK. Tel: +44 (0)20 78434567. Fax: +44 (0)20 7843 4596/4763. E-mail: m.purton@nature.com

sequenced its genome with Bob Waterston, before building the large sequencing factory that would work on the human genome. The book is co-written with science journalist Georgina Ferry.

From the very start, the architects of the Human Genome Project found themselves bedevilled by two problems. The first was how to obtain the very large resources required for the sequencing and to ensure the support of the scientific community. Second, they had to deal with several issues that are extraneous to scientific and technical matters, including patenting and the use of human genetic information. Many of those who worked on the project had previous experience of these problems, which arose with the invention of methods of cloning DNA; most of these problems are still with us today.

Many scientists were opposed to the project, partly because they saw sequencing as a mindless activity, but largely because it would be Big Science and that meant Big Money. They were worried that the project would drain resources away from their research, which is why additional support had to be generated that would not compete with existing research funds. Today the project is widely accepted, but at the outset almost everybody involved had to be dragged screaming into it. It was difficalt for most scientists to understand that genome sequencing would give us a new approach to genetics; few had experienced the illumination I had in 1977 on seeing how Fred Sanger's sequence of bacteriophage lambda gave us the amino-acid sequences of the proteins made by all of the genes of its 50-kilobase genome.

Sulston sees the publicproject as a crusade against those bent on creating a monopoly in human genome data by patenting. Chief among these is Craig Venter, who set up The Institute of Genome Research (TIGR), which was financed by Human Genome Sciences, aprivate company that patented the sequences emerging from TIGR's expanded
cDNA sequencingprogramme. The genomics 'goldrush' was created when the rights for these sequences were sold to SmithKline for $\$ 125$ million.

Other companies followed in their wake, including Incyte, which also patented sequences and kept its databases closed to all except paying customers. Sequences of human genes had been patented by many working in the public research sector, but what was new and different in the case of the human genome is that the monopoly might involve every single gene, and thus every singleprotein, in the human body.

In 1998 Venter announced that he was setting up Celera to sequence the human genome, and that he would do it well ahead of the public-sector project by using a total shotgun strategy. The public-sector group had already departed from their original pristine standards of a genome finished to $99.99 \%$ accuracy by contemplating in 1995 the production of a 'draft' sequence. Sulston tells how the public project's work towards the draft sequence was accelerated in response to Celera's challenge, and how Sulston was able to convince the Welloome Trust to increase its funding.

The race was finally declared a draw on 26 June 2000, when a joint announcement was made about the draft sequences obtained by each group. This was followed early in

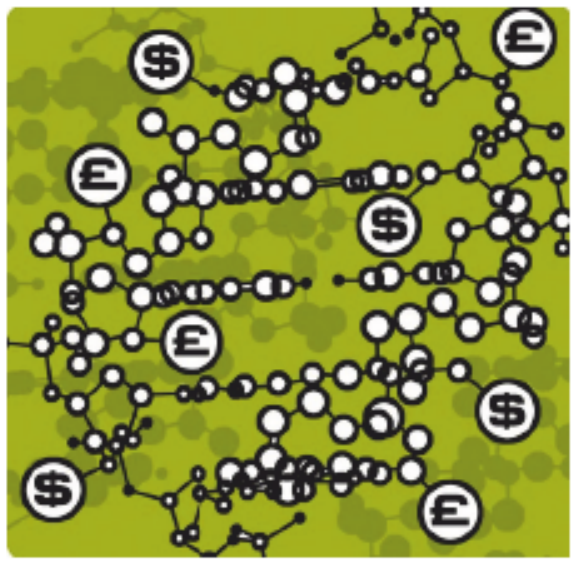

2001 by the publication of two papers, one by Celera in Science, the other by the public project in Nature. Sulston recounts how this exacerbated the angry relations between the groups.

The dominant message in the book is that the human genome sequence belongs to everybody and that we should all have free access to it. Sulston formulated the Bermuda principles, which aimed to ensure this access by the daily automatic release of all sequence assemblies of more than 1 kilobase and the immediate submission of finished sequences to the public databases. The lofty aim was to make the sequence freely available for research and development, but its prior publication also rendered sequences unpatentable for lack of novelty. It did not help the ordinary scientist very much because large computing resources were required to do anything serious with the unfinished sequences. Celera had such resources, and so were able to use the public database as well as their own data.

Sequencing large genomes has nothing to do with any intellectual endeavour. The creative work was done earlier by Fred Sanger and by others who improved the technology. The rest is about two things: money and management. As the various projects developed, their demand for money increased. The nematode sequencing project quickly consumed most of the funds available for genome work at a time when money was short.

Sulston depicts Venter as a man who would sully the human genome by making people pay to use it, a devil who needed to be defeated. There is another view: that he was more Faust than Mephistopheles. He had ambitions in science but was essentially an outsider. His talents for organization were outstanding, but if he were to create a place for himself in the sequencing world he would need resources. He could not get these from the public sector, so he turned to other sources. Commercial organizations expect a return for their money, and Venter not only accepted the faustian bargain but used the deal to try to win the race. It looks like a clever business ploy to sell more machines and use the heightened interest in genome research to raise a large amount of money. Today, the genome bubble has burst and everybody has gone to look for drugs. Will the public sector carry on to finish the human genome sequence?

What $I$ found interesting in this account is that Sulston doesn't tell us anything about the genomes he has sequenced. What did he find there that excited him? What did he learn about genes, about life, about evolution, about worlds to come? It is the play of Hamlet without Hamlet.

Sydney Brenner is at the Salk Institute, La Jolla, California 92037-1099, USA. 